\title{
Distribution of Feline Blood Types Detected in the Copenhagen Area of Denmark
}

\author{
By A. L. Jensen, A. B. Olesen and J. Arnbjerg
}

Department of Clinical Studies, The Royal Veterinary and Agricultural Unıversity, Frederiksberg, Denmark.

\begin{abstract}
Jensen, A. L., A. B. Olesen and J. Arnbjerg: Distribution of feline blood types detected in the Copenhagen area of Denmark. Acta vet. scand., 1994, 35, 121-124. - The purpose of the present study was to make the first survey of the distribution of feline AB blood types in the Copenhagen area of Denmark. A total of 244 cats (139 purebred cats and 105 Domestic Shorthair cats) were tested. $93 \%$ of all tested cats had blood type A. Neither an $\mathrm{AB}$ nor an $\mathrm{O}$ type cat was detected and thus, the frequency of blood type $\mathrm{B}$ among all tested cats was $7 \%$. Most type B cats were purebred cats (Birman, British Shorthair and Persian cats). No association between sex and blood type could be demonstrated among Britısh Shorthair and Persian cats. Thus, the present study indicates that cats in Denmark predominantly have blood type A, and that blood type B cats are rare, except for certain breeds such as Bırman and Britısh Shorthair cats.
\end{abstract}

blood groups; cat; transfusion; neonatal isoerythrolysis; fading kitten syndrome.

\section{Introduction}

In the feline $\mathrm{AB}$ Blood Group System, 3 blood types (i.e., A, B, and AB) have currently been recognized (Bell 1983, Giger, 1992). Also, it has been proposed that the feline blood types $\mathrm{A}$ and $\mathrm{B}$ are due to the action of 2 alleles at the same gene locus and that $\mathrm{A}$ is completely dominant over B (Giger et al. 1991). Accordingly, cats with blood type B are homozygous for the B allele (genotype B/B), while cats with blood type A are either homozygous for the A allele (genotype A/A) or heterozygous (genotype $\mathrm{A} / \mathrm{B}$ ). The appearance of cats with the extremely rare blood type phenotypically expressed as $\mathrm{AB}$ has not yet been fully explained (Giger et al. 1991, Giger $1992)$, though they were experimentally produced by matings of type $A B$ to other type $\mathrm{AB}$ cats or to cats with blood type B (Bell 1983).
In cats, alloantibodies against the other blood type are naturally occurring in their plasma, most pronounced in cats with blood type B (Auer \& Bell 1983, Giger 1992, Haarer \& Grunbaum 1993). Because of this, cats with blood type B are more likely to suffer haemolytic incompability reactions during transfusion of blood with the other blood type than cats with blood type A, even if the cat has not received any blood transfusion previously (Auer \& Bell 1983, Giger et al. 1989, Haarer \& Grunbaum 1993). In addition, feline neonatal isoerythrolysis due to $\mathrm{AB}$ incompatibility, a situation comparable to the Rhesus factor-induced haemolytic disease of the newborn in humans, is now considered an important cause of the fading kitten syndrome (Giger et al. 1989, Cain \& Suzuki 1985, Giger et al. 1991, Giger 1992, Haarer \& Grünbaum 1993). Hence, the distribution and frequency of the 
feline blood types (Auer \& Bell 1981, Giger et al. 1989, Giger et al. 1991, Giger 1992, Haarer \& Grunbaum 1993) and the biochemical nature of the antigens that determine the feline AB blood group system (Griot-Wenk et al. 1993) have been investigated with increasing interest.

In Denmark, information on the feline blood types were not available and thus, the purpose of this study was to make the first survey of the distribution of feline $\mathrm{AB}$ blood types in Denmark.

\section{Materials and methods}

\section{Sample collection and testing}

A total of 244 cats living in the Copenhagen area were included in the study. Approximately half of the cats were Domestic Shorthair cats $(43 \%)$ (Table 1$)$, while the other half consisted of purebred cats of various breeds, mostly Persian, British Shorthair, and Abyssinian cats. The domestic shorthair cats were all selected from patients presented at the Small Animal Hospital, Department of Clinical Studies. The pure-breed cats were presented by owners who had voluntered to have their cats tested.

0.3-2.0 ml of blood was collected by venepuncture into Vacutainers ${ }^{\circledR}$ (Beckton-Dickınson) containing $0.12 \mathrm{ml}$ of $0.34 \mathrm{~mol} / \mathrm{L}$ tripotassium ethylene diaminotetraacetate (EDTA). The blood samples were kept at $+4^{\circ} \mathrm{C}$ for a maximum of 3 days. Blood typing was performed essentially as described by Auer \& Bell (1981) and Giger et al. (1989) using antisera (anti-A and anti-B) kindly provided by Dr. U. Giger, University of Pennsylvania, Pennsylvania, U.S.A. Briefly, $0.1 \mathrm{ml}$ of whole blood was suspended in $0.9 \mathrm{ml}$ of polyphosphate buffered physiologic saline $(0.9 \% \mathrm{NaCl})$. Subsequently, $25 \mu \mathrm{l}$ of the erythrocyte suspension was added to $50 \mu$ of either anti-A or anti-B sera and the mixture was gently shaken and incubated at room temperature for $15 \mathrm{~min}$. Then, the mixture was centrifuged $(1000 \times \mathrm{g}$ for $15 \mathrm{sec})$ and agglutination was recorded as either positive or negative by visual inspection.

\section{Results}

The blood type could be determined in all of the 244 cats included in the survey. The results of the blood typing are given in Table 1 . Neither cats with blood type 0 (i.e. no agglutination when incubated with either anti-A or anti-B sera) nor cats with blood type AB (i.e. agglutination with both anti-A and anti-B sera) were detected. Among the purebred cats, blood type B was detected only in Birman, British Shorthair and Persian cats. In Birman cats, 3 out of 5 tested cats had blood type B, while the frequency of blood type B in British Shorthair and Persian cats was 33.3\% and $3.6 \%$, respectively. Of the British Shorthair cats, 8 females and 2 males had blood type B, while blood type A was encountered in 11 females and 9 males. In the Persian cats, 18 males and 36 females had blood type $\mathrm{A}$, while blood type B was detected only in 2 females. A significant association between sex and blood type could not be detected by the use of the Fisher exact test and a significance level of 0.05 , neither among British Shorthair cats nor among Persian cats.

\section{Discussion}

The present study estimates the distribution of blood types in various cat breeds in the Copenhagen area of Denmark. Thus, it is not known whether the observed distribution also reflects the general distribution of feline blood types in Denmark.

The distribution of feline blood types varies in different countries, the lowest frequency of blood type A (73\%) being found in Australia (Auer \& Bell 1981). However, the distribution 
Table 1. Distribution of blood types in various cat breeds as obtained in the Copenhagen area of Denmark.

\begin{tabular}{|c|c|c|c|c|c|}
\hline Breed & $\begin{array}{l}\text { Total number } \\
\text { of cats }\end{array}$ & $\begin{array}{l}\text { Blood type } \\
\text { number }\end{array}$ & $\mathrm{A}_{(\%)}$ & $\begin{array}{l}\text { Blood typ } \\
\text { number }\end{array}$ & (\%) \\
\hline Abyssinian & 20 & 20 & $(100)$ & 0 & (0) \\
\hline Birman & 5 & 2 & $(40)$ & 3 & (60) \\
\hline Britısh Shorthair & 30 & 20 & $(66.7)$ & 10 & (33.3) \\
\hline Burmese & 9 & 9 & $(100)$ & 0 & (0) \\
\hline Europée & 1 & 1 & $(100)$ & 0 & (0) \\
\hline Exotic Shorthair & 1 & 1 & $(100)$ & 0 & (0) \\
\hline Maine Coon & 3 & 3 & $(100)$ & 0 & (0) \\
\hline \multicolumn{6}{|l|}{ Norwegian } \\
\hline Forest & 2 & 2 & $(100)$ & 0 & (0) \\
\hline Persian & 56 & 54 & (96.4) & 2 & (3.6) \\
\hline Siamese & 3 & 3 & (100) & 0 & (0) \\
\hline Somalı & 9 & 9 & $(100)$ & 0 & (0) \\
\hline All purebred cats & 139 & 124 & $(89.2)$ & 15 & (10.8) \\
\hline Domestic shorthair & 105 & 103 & (98.1) & 2 & (1.9) \\
\hline All tested cats & 244 & 227 & (93.0) & 17 & (7.0) \\
\hline
\end{tabular}

of blood types among the various cat breeds as determined in this study is largely comparable to the distribution of blood types found in other countries (Giger et al. 1989, Giger et al. 1991, Giger 1992, Haarer \& Grübaum 1993). The main discrepancy is the frequency of blood type B in Birman cats, which is $60.0 \%$ in this study and $17.6 \%$ in the study of Giger et al. (1991). The reason for this discrepancy is most likely the low number of Birman cats in this study. The present study demonstrates that blood type B is commonly occurring in British Shorthair cats. This is in accordance with previous reports, which, beside the British Shorthair cats, also indicate that blood type $B$ is frequently occurring in other breeds such as Cornish Rex and Devon Rex cats (Giger et al. 1991, Giger 1992, Haarer \& Grünbaum 1993). Thus, British Shorthair, Cornish Rex and Devon Rex cats may have a higher risk of haemolytic incompatibility reactions and neonatal isoerythrolysis compared to other cat breeds. Besides the associ- ation between breed and blood type, a significant association between sex and blood type has been reported by Haarer \& Grunbaum (1993), who found that blood type A was more common in male cats than in female cats. This was, however, not detected in the present study, perhaps because of the limited number of animals available for such a comparison.

To conclude, the present study indicates that cats in Denmark predominantly have blood type A, and that blood type B cats are rare, except for certain breeds such as Birman and British Shorthair cats.

\section{Acknowledgements}

The skillful technical assistance of Ms. D. B. Madsen, Ms. E. Thomsen, Ms. V.S. Østvedt, Ms. H. Bırkkjær, Ms. K. Faber, and Ms. R. Cohrt is gratefully acknowledged.

\section{References}

Auer L, Bell K: The AB blood group system of cats. Anım. Blood Groups B1ochem. Genet. 1981, 12, 287-297. 
Auer $L$, Bell $K^{\cdot}$ Transfusion reactions in cats due to AB blood group incompability. Res. Vet. Sc1. $1983,35,145-152$.

Bell $K$. The blood groups of domestic anımals. In: Agar N S, Board P G. (Eds): Red blood cells of domestıc anımals, Elsevier, Amsterdam 1983, p. 133-164.

Cain GR, Suzukı Y· Presumptive neonatal isoerythrolysis in cats. JAVMA 1985, 187, 46-48.

Glger U, Kilrain CG, Filippich LJ, Bell K· Frequencies of feline blood groups in the United States. JAVMA 1989, 195, 1230-1232.

Giger U, Bucheler J, Patterson DF Frequency and inheritance of A and B blood types in feline breeds of the United States. J. Heredity 1991, 82, 15-20.

Giger $U$. The feline $\mathrm{AB}$ blood group system and incompability reactıons. In: Kırk R W, Bonagura J D. (Eds): Kırk's Current Veterinary Therapy XI, Small Anımal Practice, W. B. Saunders Company, Phıladelphia 1992, p. 470-474.

Griot-Wenk M, Pahlsson P, Chisholm-Chalt A, Spttalnık PF, Spıtalnık SL, Gıger U. Biochemıcal characterization of the feline $\mathrm{AB}$ blood group system Anımal Genetics 1993, 24, 401-407

Haarer M, Grunbaum EG Blutgruppenserologische Untersuchungen be1 Katzen in Deutschland.
(Serological investigations of blood groups in cats in Germany). Kleıntierpraxıs 1993, 38, 195204.

\section{Sammendrag \\ Blodtyper hos katte ı Københavnsområdet}

Denne undersøgelse beskriver for første gang forekomsten af blodtyperne A og B blandt forskellige katteracer 1 Hovedstadsområdet 1 Danmark. 139 racekatte og 105 almındelige huskatte, alle fra Københavns området, inkluderedes 1 undersøgelsen. Der fandtes ingen katte med blodtype $\mathrm{AB}$ eller blodtype O. Blodtype A var den hyppigst forekommende (93\% blandt alle 244 unders $\varnothing$ gte katte) Blodtype B forekom især hos racekatte og især hos Birma, British Shorthair og Perserkatte. Hos almindelige huskatte var hyppigheden af blodtype B 1,9\%. Der kunne 1 kke påvises nogen sammenhæng mellem $k ø n$ og blodtype hos hverken Britsh Shorthair eller Perserkatte. Undersøgelsen indıkerer således, at blodtype A er den hyppigst forekommende blodtype hos katte 1 Hovedstadsområdet 1 Danmark, medens katte med blodtype B, bortset fra Birma og Britısh Shorthair katte, er sjældne.

(Recelved September 22, 1993; accepted December 22, 1993).

Reprints may be requested from: A. L. Jensen, Small Anımal Hospital, Department of Clinial Studies The Royal Veterınary and Agricultural Unıversity, Bulowsvej 13, DK-1870 Frederıksberg C, Denmark 